\title{
Natural Trace Element Distribution Coefficients for Garnet, Clino- and Orthopyroxene: Variations with Temperature and Pressure
}

\author{
Van Achterbergh, E. ${ }^{1}$, Griffin, W.L. ${ }^{1,2}$, Shee, S.R. ${ }^{3}$, Wyatt, B.A. ${ }^{3}$ and Sharma, A.L. ${ }^{1}$ \\ 1. GEMOC National Key Centre, School of Earth Sciences, Macquarie University, NSW 2109, Australia \\ 2. CSIRO Exploration and Mining, P.O. Box 136, North Ryde, NSW 2113, Australia \\ 3. Stockdale Prospecting Ltd., P.O. Box 126, South Yarra, VIC 3141, Australia
}

Knowledge of the distribution of elements in minerals is an essential tool for modelling anatectic and metasomatic processes in the upper mantle. Using the high sensitivity Laser Ablation ICP-MS microprobe, new data on the partitioning of trace and rare earth elements (REE) between garnet and pyroxene have been obtained This study is based on a suite of peridotite xenoliths from the Wesselton kimberlite pipe and reports preliminary results for the partitioning of these elements between garnet, clinopyroxene (cpx) and orthopyroxene (opx). Petrographic investigation and detailed electron microprobe analysis of the major elements established that the minerals are homogeneous and likely to be in chemical equilibrium.

Compositional variation (for the major elements) within the selected suite is minimal (with one exception), whereas a range in temperature $(\mathrm{T})$ and pressure $(\mathrm{P})$ is represented. This allows an investigation of the effects that these physical parameters have on the distribution of the elements, independent of compositional effects. In accordance with Watson (1985), deviation from Henry's Law is assumed to be negligible. Details of the major element compositions are given in Table 1 and the trace and REE distribution coefficients are listed in Table 2.

Table 1: Major element data for the Wesselton xenoliths. All values in weight\%, ND = not detected. $\mathrm{T}$ from Griffin et al. (1989) and Ryan et al., (1996), P from Finnerty and Boyd (1984).

\begin{tabular}{cccccccccccccc}
\hline Sample & $\mathrm{SiO}_{2}$ & $\mathrm{TiO}_{2}$ & $\mathrm{Al}_{2} \mathrm{O}_{3}$ & $\mathrm{Cr}_{2} \mathrm{O}_{3}$ & $\mathrm{FeO}$ & $\mathrm{MnO}$ & $\mathrm{MgO}$ & $\mathrm{CaO}$ & $\mathrm{Na}_{2} \mathrm{O}$ & $\mathrm{K}_{2} \mathrm{O}$ & $\mathrm{T}\left({ }^{\circ} \mathrm{C}\right)$ & $\mathrm{P}(\mathrm{kbar})$ \\
\hline $959 \mathrm{gt}$ & 40.3 & 0.03 & 20.9 & 3.73 & 8.34 & 0.47 & 19.4 & 5.25 & 0.03 & $\mathrm{ND}$ & 872 & 36 \\
$960 \mathrm{gt}$ & 39.8 & 0.05 & 20.6 & 3.79 & 8.34 & 0.55 & 19.9 & 5.01 & 0.04 & $\mathrm{ND}$ & 809 & 32 \\
$965 \mathrm{gt}$ & 39.9 & 0.07 & 21.1 & 3.24 & 8.26 & 0.44 & 19.9 & 4.90 & 0.03 & $\mathrm{ND}$ & 819 & 33 \\
$966 \mathrm{gt}$ & 40.0 & 0.03 & 18.6 & 6.69 & 7.18 & 0.36 & 19.7 & 5.89 & 0.03 & $\mathrm{ND}$ & 997 & 46 \\
$968 \mathrm{gt}$ & 40.6 & 0.04 & 20.6 & 3.89 & 7.30 & 0.42 & 20.2 & 5.24 & 0.03 & $\mathrm{ND}$ & 1013 & 46 \\
$959 \mathrm{cpx}$ & 53.8 & 0.09 & 2.23 & 1.83 & 2.15 & 0.07 & 15.6 & 21.0 & 1.93 & 0.01 & 872 & 36 \\
$960 \mathrm{cpx}$ & 53.8 & 0.13 & 3.03 & 2.17 & 2.50 & 0.02 & 14.6 & 19.8 & 2.65 & 0.01 & 809 & 32 \\
$965 \mathrm{cpx}$ & 54.4 & 0.14 & 2.48 & 2.07 & 2.29 & 0.06 & 15.3 & 20.6 & 2.11 & $\mathrm{ND}$ & 819 & 33 \\
$966 \mathrm{cpx}$ & 53.8 & 0.03 & 2.23 & 2.44 & 2.28 & 0.07 & 16.0 & 19.4 & 2.26 & 0.01 & 997 & 46 \\
$968 \mathrm{cpx}$ & 54.0 & 0.02 & 1.73 & 1.40 & 2.26 & 0.10 & 17.0 & 20.9 & 1.44 & 0.02 & 1013 & 46 \\
$994 \mathrm{cpx}$ & 53.1 & 0.04 & 2.51 & 2.18 & 2.25 & 0.05 & 15.0 & 20.6 & 2.25 & 0.01 & 821 & 34 \\
$995 \mathrm{cpx}$ & 52.6 & 0.17 & 2.36 & 1.66 & 2.43 & 0.03 & 15.4 & 20.8 & 2.02 & $\mathrm{ND}$ & 851 & 36 \\
$996 \mathrm{cpx}$ & 53.3 & 0.06 & 2.24 & 1.86 & 2.25 & 0.04 & 15.4 & 21.0 & 1.91 & 0.01 & 862 & 36 \\
$1001 \mathrm{cpx}$ & 52.7 & 0.45 & 2.28 & 2.41 & 3.71 & 0.10 & 16.8 & 17.7 & 1.96 & 0.01 & 1080 & 51 \\
$1007 \mathrm{cpx}$ & 54.0 & 0.25 & 2.31 & 2.40 & 2.38 & 0.07 & 16.2 & 18.5 & 2.29 & 0.05 & 1047 & 49 \\
$994 \mathrm{opx}$ & 57.0 & 0.02 & 0.72 & 0.26 & 4.94 & 0.12 & 36.6 & 0.25 & 0.06 & 0.002 & 821 & 34 \\
$995 \mathrm{opx}$ & 57.5 & 0.06 & 0.72 & 0.22 & 5.27 & 0.12 & 36.1 & 0.26 & 0.07 & 0.004 & 851 & 36 \\
$996 \mathrm{opx}$ & 57.5 & 0.03 & 0.74 & 0.26 & 5.05 & 0.11 & 36.3 & 0.27 & 0.04 & 0.002 & 862 & 36 \\
1001 opx & 56.9 & 0.06 & 0.69 & 0.42 & 6.45 & 0.12 & 34.6 & 0.62 & 0.16 & 0.006 & 1080 & 51 \\
1007 opx & 57.7 & 0.06 & 0.70 & 0.37 & 4.39 & 0.14 & 36.1 & 0.58 & 0.17 & $\mathrm{ND}$ & 1047 & 49 \\
\hline
\end{tabular}

Garnet - Clinopyroxene Partitioning: A comparison of the new distribution coefficient data from Wesselton with data available in the literature (and some unpublished data), shows generally good agreement (Figure 1). This is despite the fact that the trace element composition of both the garnet and cpx reflects extensive metasomatism, which is commonly accompanied by the introduction of phlogopite. This suggests that regardless of the secondary processes involved, equilibration had been achieved before entrainment in the kimberlite. 
The positive $\mathrm{Nb}$ and $\mathrm{Zr}$ anomalies in the otherwise smooth curves of the distribution coefficient plot are consistent with the literature data and with the experimental findings of Green et al. (1989) that the high field strength elements (HFSE) tend to concentrate in garnet. The distribution is controlled dominantly by the crystal chemistry, and the better fit of these ions into the garnet structure. As the temperature increases, thermal expansion of the lattice allows more $\mathrm{Zr}$ to enter garnet and $\mathrm{D}_{\mathrm{Zr}}$ (garnet/cpx) therefore increases with increasing temperature. In accordance with the results of O'Reilly and Griffin (1995), no pressure effect was observed on the distribution of these elements between cpx and garnet. The distribution of $\mathrm{Ti}$ also appears to be temperature dependent. However, data from peridotite xenoliths in basalts from eastern China (Xu et al., 1998), suggest that pressure plays a more important role in the partitioning of $\mathrm{Ti}$. The calculated pressures for these samples are lower than those measured for the Wesselton suite (19-20 kbar vs 32-46 kbar), while the temperature is higher $\left(1117^{\circ} \mathrm{C}-1146^{\circ} \mathrm{C}\right.$ vs $\left.809^{\circ} \mathrm{C}-1013^{\circ} \mathrm{C}\right)$. The differences between the Chinese and South African samples indicate that at lower pressure, Ti prefers the cpx structure $\left(\mathrm{D}_{\mathrm{Ti}}(\mathrm{garnet} / \mathrm{cpx})<1\right)$, and at higher pressure the garnet structure $\left(\mathrm{D}_{\mathrm{Ti}}(\right.$ garnet/cpx $\left.)>1\right)$. Although the two suites are broadly similar in composition (calcic lherzolitic garnet and diopside), the Chinese cpx contain slightly less Ca and the garnet less $\mathrm{Cr}$, which may have some effect on this trend.

Higher temperature and pressure also increase the D (garnet/cpx) for the light-(L) and medium(M) REE, but have no observable effect on the heavy REE. Therefore, the slope of the distribution coefficient curve changes, becoming shallower at higher temperature. This is consistent with the data of Mazzucchelli et al. (1992) on crustal garnet-cpx pairs, which are at the lowest temperature (around $800{ }^{\circ} \mathrm{C}$ ) and show the steepest slope, and with the flatter slope of Hauri et al.'s (1994) experimental data at $1430^{\circ} \mathrm{C}$ (Figure 1$)$.

Table 2: Trace and rare earth element distribution coefficients for garnet-cpx and cpx-opx pairs

\begin{tabular}{|c|c|c|c|c|c|c|c|c|c|c|}
\hline Element & $\begin{array}{l}\text { gt/cpx } \\
959\end{array}$ & $\begin{array}{l}g t / c p x \\
960\end{array}$ & $\begin{array}{l}\mathrm{gt} / \mathrm{cpx} \\
965\end{array}$ & $\begin{array}{l}\text { gt/cpx } \\
966\end{array}$ & $\begin{array}{l}\text { gt/cpx } \\
968\end{array}$ & $\begin{array}{l}\text { cpx/opx } \\
994\end{array}$ & $\begin{array}{l}\text { cpx/opx } \\
995\end{array}$ & $\begin{array}{l}\text { cpx/opx } \\
996\end{array}$ & $\begin{array}{l}\text { cpx/opx } \\
1001\end{array}$ & $\begin{array}{l}\text { cpx/opx } \\
1007\end{array}$ \\
\hline $\mathrm{Sr}$ & 0.0007 & 0.0007 & 0.0004 & 0.0023 & 0.0013 & 305 & 156 & 354 & 161 & 392 \\
\hline $\mathbf{N b}$ & 0.564 & 0.284 & 0.190 & 0.559 & 1.15 & & & & & \\
\hline $\mathbf{L a}$ & 0.008 & 0.007 & 0.003 & 0.022 & 0.013 & 151 & 149 & 186 & 59.8 & 13.3 \\
\hline $\mathrm{Ce}$ & 0.009 & 0.008 & 0.006 & 0.034 & 0.030 & 129 & 218 & 456 & 50.3 & \\
\hline $\mathrm{Pr}$ & 0.032 & 0.016 & 0.022 & 0.078 & 0.081 & & & & & \\
\hline Nd & 0.064 & 0.052 & 0.047 & 0.191 & 0.172 & & & & & \\
\hline $\mathbf{Z r}$ & 0.760 & 0.540 & 0.563 & 2.28 & 3.89 & 102 & 140 & 114 & 46.3 & 75.6 \\
\hline Hf & 0.230 & 0.153 & 0.165 & 1.00 & 1.54 & & & & & \\
\hline $\mathrm{S} \mathbf{m}$ & 0.344 & 0.319 & 0.273 & 0.832 & 0.722 & 86.8 & 12.3 & & 7.87 & \\
\hline Eu & 0.486 & 0.643 & 0.597 & 1.00 & 0.955 & & & & & \\
\hline $\mathbf{T i}$ & 0.947 & 0.640 & 0.524 & 1.56 & 7.93 & 2.25 & 2.39 & 2.15 & 12.6 & 2.74 \\
\hline Gd & 1.01 & 0.952 & 1.39 & 1.42 & 1.63 & 11.5 & 6.00 & & 9.37 & \\
\hline D y & 3.51 & 4.21 & 6.11 & 4.57 & 2.48 & & & & & \\
\hline Ho & 6.50 & 6.72 & 10.2 & & 1.16 & & & & & \\
\hline $\mathbf{Y}$ & 9.25 & 9.29 & 9.78 & 8.84 & 8.34 & 75.3 & 55.1 & & 52.0 & 30.5 \\
\hline $\begin{array}{l}\mathbf{E r} \\
\mathrm{Y}\end{array}$ & 6.70 & 8.56 & 14.5 & & 1.71 & 0.919 & & & 1.63 & \\
\hline $\mathrm{Lu}$ & 3.47 & 4.87 & & & 3.33 & & & & & \\
\hline S c & 4.10 & 3.23 & 3.67 & 5.17 & 6.89 & 9.47 & 10.3 & 10.0 & 6.47 & 7.67 \\
\hline $\mathbf{G a}$ & 1.27 & 0.982 & 1.09 & 1.89 & 2.27 & 1.31 & 1.51 & 1.52 & 2.14 & 1.58 \\
\hline $\mathbf{V}$ & 0.411 & 0.318 & 0.350 & 0.712 & 0.875 & 8.38 & 8.35 & 7.88 & 5.72 & 6.26 \\
\hline Co & 2.78 & 2.66 & 3.14 & 2.25 & 2.21 & 0.242 & 0.240 & 0.251 & 0.333 & 0.309 \\
\hline $\mathbf{N i}$ & 0.090 & 0.083 & 0.094 & 0.125 & 0.120 & 0.332 & 0.332 & 0.351 & 0.429 & 0.373 \\
\hline $\mathrm{CaO}$ & 0.250 & 0.252 & 0.237 & 0.304 & 0.250 & 52.2 & 60.4 & 70.8 & 22.7 & 28.2 \\
\hline
\end{tabular}




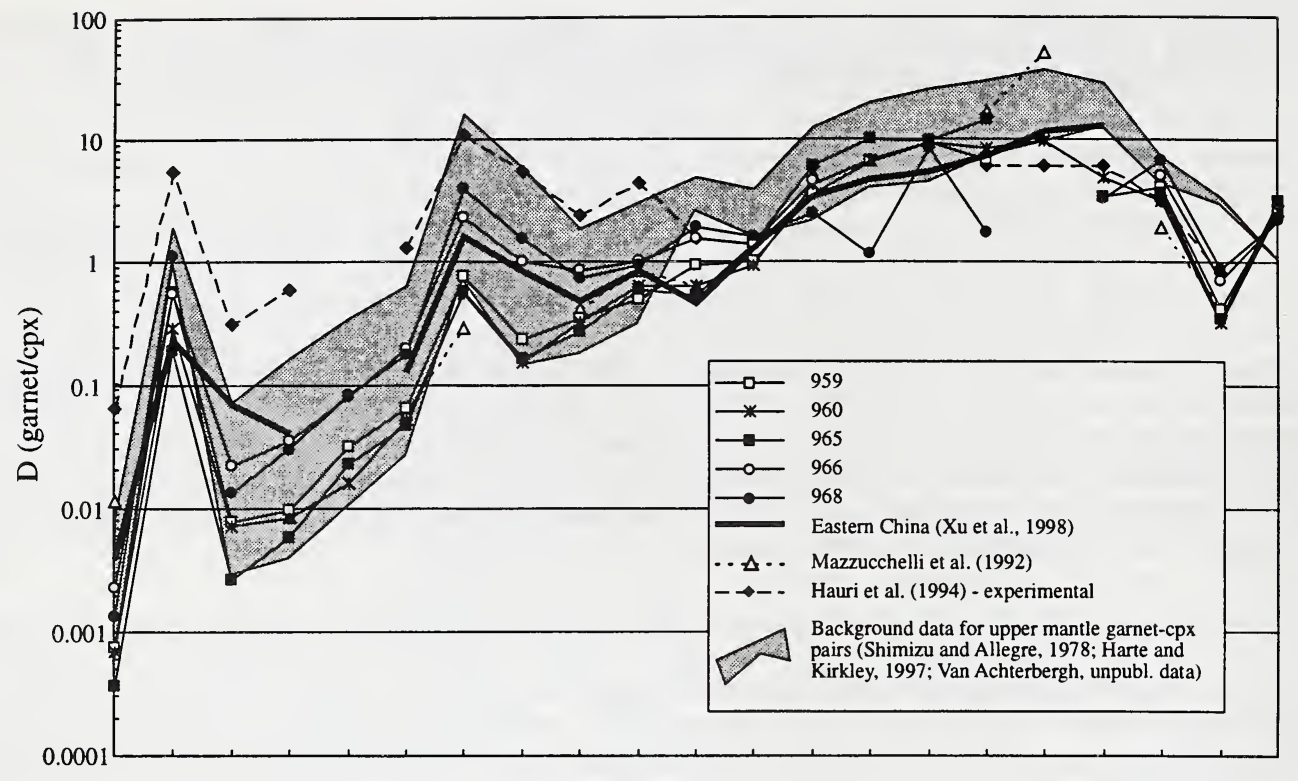

$\begin{array}{lllllllllllllllllllll}\mathrm{Sr} & \mathrm{Nb} & \mathrm{La} & \mathrm{Ce} & \mathrm{Pr} & \mathrm{Nd} & \mathrm{Zr} & \mathrm{Hf} & \mathrm{Sm} & \mathrm{Eu} & \mathrm{Ti} & \mathrm{Gd} & \mathrm{Dy} & \mathrm{Ho} & \mathrm{Y} & \mathrm{Er} & \mathrm{Yb} & \mathrm{Lu} & \mathrm{Sc} & \mathrm{V} & \mathrm{Co}\end{array}$

Figure 1: Garnet-cpx distribution coefficients for Wesselton xenoliths and comparative literature data

Clinopyroxene - Orthopyroxene Partitioning:

Published data on cpx-opx partitioning are scarce, and a comprehensive comparison is not possible. However, where data are available (eg. McDonough et al., 1992) good agreement exists between datasets. The LREE abundances in opx are very low, and the data are characterised by large standard deviations. Of the elements analysed (Table 1), only Co and Ni prefer the opx structure. Ga and Er partition approximately equally and all other elements fit more easily into cpx. The well-documented $\mathrm{T}$ dependent partitioning of $\mathrm{Ca}$ into opx (Brey and Köhler, 1990) is evident in these data: as $\mathrm{T}$ increases, so the $\mathrm{Ca}$ in opx increases. The LREE, $\mathrm{Zr}, \mathrm{Sc}$ and $\mathrm{V}$ follow the same trend. A single sample $(1001)$ has lower $\mathrm{X}_{\mathrm{Mg}}(0.81)$ than the rest of the suite (0.84-0.86) and as Mg decreases, more LREE, and fewer HREE enter the crystal structure. The Ti distribution coefficient also increases markedly as $\mathrm{X}_{\mathrm{Mg}}{ }^{\text {opx }}$ decreases.

\section{References Cited}

Brey, G.P. and Köhler, T. (1990). J. Petrol., 31, 1353-1378

Finnerty, A.A. and Boyd, F.R. (1984). Geochim. Cosmochim. Acta, 48, 15-27

Green, T.H., Sie, S.H., Ryan, C.G. and Cousens, D.R. (1989). Chemical Geology, 74, 201-216

Griffin,W.L., Cousens,D.R., Ryan,C.G., Sie,S.H. and Suter,G.F.(1989). Contrib. Mineral. Petrol. 103, 199-202

Harte, B. and Kirkley, M.B. (1997). Chemical Geology, 136, 1-24

Hauri, E.H., Wagner, T.P. and Grove, T.L. (1994). Chemical Geology, 117, 149-166

Mazzucchelli, M., Rivalenti, G., Vannucci, R., Bottazzi, P., Ottolini, L., Hofmann, A.W., Sinigoi, S. and Demarchi, G. (1992). Geochim. Cosmochim. Acta, 56, 2371-2385

McDonough, W.F., Stosch, H.G. and Ware, N.G. (1992). Contrib. Mineral. Petrol., 110, 321-328

O'Reilly, S.Y. and Griffin, W.L. (1995). Chemical Geology, 121, 105-130

Ryan, C.G., Griffin, W.L. and Pearson, N.J. (1996). J. Geophys. Res. 101, 5611-5625.

Shimizu, N. and Allègre, C.J. (1978). Contrib. Mineral. Petrol. 67, 41-50

Watson, E.B. (1985). Geochim. Cosmochim. Acta, 49, 917-923

Xu, X., O'Reilly, S.Y., Griffin, W.L., Zhou, X and Huang, X. (1997).In: Mantle Dynamics and Plate Interactions in

East Asia (Flower, M., Chung, S.L., Lo, C.H. and Lee, T.Y., eds). Amer. Geophys. Union Spec. Publ., in press 